\title{
Natural Varroa mite-surviving Apis mellifera honeybee populations
}

\author{
Barbara LOCKE \\ Department of Ecology, Swedish University of Agricultural Sciences, PO Box 7044, 750 07, Uppsala, Sweden
}

Received 18 April 2015 - Revised 28 September 2015 - Accepted 6 November 2015

\begin{abstract}
The Varroa destructor mite is the largest threat to apiculture worldwide and has been responsible for devastating losses of wild honeybee populations in Europe and North America. However, Varroa mite-resistant populations of $A$. mellifera honeybees have been reported and documented around the world with a variety of explanations for their long-term survival with uncontrolled mite infestation. This review synthesizes the work on naturally occurring survival to Varroa mites and discusses what these honeybee populations can signify for apiculture.
\end{abstract}

Varroa destructor / mite resistance / host-parasite adaptations / natural selection / apiculture

\section{INTRODUCTION}

The European honeybee, Apis mellifera, is the only Apis species that does not have a natural parasitic brood mite but is nevertheless highly susceptible to at least two mites that are native to other honeybee species (Varroa destructor and Tropilaelaps clareae; Oldroyd 1999). The ectoparasitic mite, Varroa destructor, is of particular importance as it is currently considered the largest threat to apiculture worldwide and inflicts more damage and higher economic costs than all other known apicultural diseases (Boecking and Genersch 2008).

The Varroa mite's natural host is the Asian hive bee, Apis cerana. Damage to Asian honeybee colonies is rarely experienced since a stable host-parasite relationship has been established over a long evolutionary scale (Rath 1999). Such a relationship is distinguishably missing with the European honeybee. In Asian hive bee colonies,

Corresponding author: B. Locke, barbara.locke@slu.se Manuscript editor: Yves Le Conte the mite's reproduction is restricted to drone brood (Boot et al. 1999). and when mites try to enter worker brood cells, the infested pupa along with the mites are removed by the hygienic behavior of adult bees (Peng et al. 1987). Also, adult bees with grooming behavior capture and kill the phoretic mites in the colony (Peng et al. 1987).

European honeybees have behavioral defenses similar to the Asian hive bee such as grooming and hygienic behavior but they are typically less pronounced (Fries et al. 1996) and variable between A. mellifera races (Moretto 2002; Moretto et al. 1991a). The specific removal of mite-infested brood has been termed Varroa -sensitive hygienic (VSH) behavior (Harris 2007; Ibrahim and Spivak 2006; Spivak 1996). Both hygienic behavior and VSH behavior remove dead or diseased brood, as well as mite-infested brood, but the later is more effective toward mite infestation (Boecking and Spivak 1999; Ibrahim and Spivak 2006; Danka et al. 2013). The distinction between VSH behavior and regular hygienic behavior may be in the detection stimulus of the adult bees which for VSH seems to be indirect effects of mite infestation such as pupal virus levels or faults in pupal development (Mondet 2014). Differentiating between 
these behaviors in a colony is difficult and depends on how the behavior is measured. This review distinguishes these behaviors based on the testing methods in the original work. Whether the mite removal is due to general hygienic behavior or VSH behavior, most mites are not killed and instead escape during the removal process. Nevertheless, this results in an interruption of the mite's reproductive cycle, which can slow down the mite population growth (Boecking and Spivak 1999).

Since the Varroa mite made the host switch to the European honeybee, it has successfully spread throughout the world, and today, only Australia and a few isolated locations and islands are considered mite-free (Rosenkranz et al. 2010). In Europe and North America, the Varroa mite has caused devastating losses of wild A. mellifera honeybee populations in these regions (Le Conte et al. 2010; Neumann and Carreck 2010). The Varroa destructor species includes several mitochondrial haplotypes, but only two are able to reproduce in $A$. mellifera colonies: the Korean haplotype that has a worldwide distribution and the Japanese haplotype that has only been reported in Japan, Thailand, and North and South America and is considered less virulent than the Korean type (Anderson and Trueman 2000; de Guzman and Rinderer 1999).

The big difference between the Asian and European bee species is that the mite is able to reproduce in worker brood cells of $A$. mellifera honeybees (Boot et al. 1999). This results in an exponential mite population growth (Fries et al. 1994) that can lead to colony death typically within a few years if mite population control is not practiced by beekeepers (Boecking and Genersch 2008). While feeding on bee hemolymph, the mite damages the developing worker pupae (De Jong et al. 1982; Schneider and Drescher 1987; Kralj et al. 2007) and is associated to several lethal honeybee viruses (Bailey and Ball 1991; Ball and Allen 1988). Deformed wing virus (DWV) is the most prevalent honeybee virus worldwide due to Varroa-mediated transmission and replication (de Miranda and Genersch 2010; Sumpter and Martin 2004; Rosenkranz et al. 2010).

Despite this grave situation, survival of the mite is documented in A. mellifera honeybees, most notably in the African race, Apis mellifera scutellata, in Brazil (Rosenkranz 1999) and more recently in Africa (Allsopp 2006). Even small subpopulations of European races have been well documented as surviving with uncontrolled Varroa mite infestation for a decade or longer (De Jong and Soares 1997; Fries et al. 2006; Le Conte et al. 2007; Rinderer et al. 2001; Seeley 2007). These populations of $A$. mellifera honeybees surviving Varroa mites may reveal genetic and ecological factors that enable mite resistance including important mite-resistant traits that could be adopted in breeding programs. This review synthesizes the documentation of Varroa mite-surviving populations and discusses what their long-term survival with Varroa can signify for apiculture.

\section{MITE-SURVIVING POPULATIONS}

\subsection{A. m. scutellata in Brazil and South Africa}

The Varroa mite was first reported in Africanized honeybees in Brazil in the early 1970s (Goncalves and De Jong 1981). Originally, the Japanese haplotype was described but is now replaced by the Korean haplotype on most of the continent (de Guzman and Rinderer 1999; Anderson and Trueman 2000; Rosenkranz et al. 2010). Initially, the presence of the mite in Brazil was thought to pose a serious threat, since high infestation rates were recorded (Morse and Goncalves 1979). However, a subsequent reduction in mite infestation was observed that suggested an adaptive process by the host in the population (Moretto et al. 1995). Africanized bees do not require mite control and maintain lower mite infestation rates (3-4 mites/ 100 bees) than any other $A$. mellifera race (Rosenkranz 1999; Moretto et al. 1995).

Hygienic and grooming behavior are important mite-resistant host traits of Africanized bees in Brazil (Correa-Marques and De Jong 1998; Moretto 2002; Moretto et al. 1993) and in Mexico (Guzman-Novoa et al. 1999; Mondragon et al. 2005). Lower brood attractivity for reproducing mites has been reported in Africanized honeybees (Guzman-Novoa et al. 1999), but the trait could not be attributed to larval volatiles since 
differences in volatiles with that of European races were not found (Aumeier et al. 2002).

Mite fertility has been observed as low as $50 \%$ in Africanized honeybees in Brazil (Rosenkranz and Engels 1994; Rosenkranz 1999) but has increased over the years to $>80 \%$, probably due to the replacement of the less virulent Japanese mite haplotype by the more virulent Korean mite haplotype (de Guzman and Rinderer 1999; Garrido et al. 2003). Carneiro et al. 2007 reported an increase of mite fertility in Brazil from $56 \%$ in the 1980 s to $86 \%$ in 2005-2006. Mite haplotype virulence could also explain the higher mite fertility rates found in Africanized honeybees in Mexico since only the Korean haplotype has been found there (Medina and Martin 1999; Mondragon et al. 2005; de Guzman and Rinderer, 1999; de Guzman et al. 1999).

Despite an increase in mite fertility or the presence of the Korean mite haplotype, the Africanized honeybee population remains stable in Brazil and there have been no reports of increased mite infestation rates (Carneiro et al. 2007; Garrido et al. 2003; Vandame and Palacio 2010). This suggests that mite resistance in this population is (a) based on host factors rather than parasitic virulence and (b) probably owing to a combination of traits additively reducing the mite population growth rather than a single trait alone, such as reduced mite fertility.

Since the mite was introduced to South Africa in 1997, South African bee races (A. m. scutellata and $A . m$. capensis) have been effectively mite resistant and mite control is not required (Allsopp 2006). By contrast to Brazil, only the Korean mite haplotype has been reported in this region (Anderson and Trueman 2000). When the mite was found in South Africa, mites reproduced as successfully in A. m. scutellata brood as they did in European races and it was suspected that apiculture in Africa would experience a similar negative impact from the presence of mites (Martin and Kryger 2002). Some colony losses were reported just after the mite was introduced, but the situation is now stable, which could suggest that an adaptive response by the host has occurred in response to mite infestation (Allsopp 2006). Even though Varroa mites are extremely common in
South Africa, infestation rates never exceed 4 mites/100 bees (Strauss et al. 2013).

The Varroa mite has since been found in Eastern Africa in early 2009, including Kenya, Tanzania, and Uganda with even a few observations in Ghana suggesting a now westward spread of the mite across Africa (Frazier et al. 2010). Beekeepers in these countries were not even aware of the presence of the mite nor have they experienced any negative impact on colony survival or productivity (Frazier et al. 2010). Previously, A. m. intermissa honeybees in Tunisia have been described as mite-resistant with increased grooming and hygienic behavior (Boecking and Ritter 1993). Kefuss et al. (2004) imported $A$. m. intermissa queens to France and have observed reduced mite infestations in their hybrids.

The Africanized bees of Brazil are genetically identical to their ancestral African race, A. m. scutellata, due to genotypic qualities that outcompete the European race (Schneider et al. 2004). Therefore, the mite resistance of $A$. m. scutellata honeybees in both Brazil and Africa could be explained by shared pre-existing genetic elements of parasitic resistance. Besides active defensive behaviors, additional characteristics of the $A . m$. scutellata race that may in combination support low mite population growth include higher rates of absconding, migratory swarming, faster colony development, and generally smaller colonies (Fletcher 1978; Moritz and Jordan 1992; Schneider et al. 2004). Further, a reduced bee developmental time (Buchler and Drescher 1990; Moritz and Jordan 1992; Rosenkranz and Engels 1994) and reduced comb cell size (Message and Goncalves 1995; Medina and Martin 1999; Piccirillo and De Jong 2004) can reduce the ability of mother mites to produce viable mated female offspring before the adult bee emerges from the cell. However, Seeley and Griffin (2011) have clearly demonstrated that small comb cell size did not reduce Varroa mite infestations for European races of $A$. mellifera . Climate has also been suggested to play a role in reduced mite infestation (Moretto et al. 1991b). Although it is more likely that climate indirectly affects mite population growth by regulating honeybee brood amounts or 
influencing the activeness of bee defense behaviors (Rosenkranz et al. 2010).

Virus infections have been detected at low levels in South African bees but do not seem to affect the health status of these colonies, and DWV was notably absent (Strauss et al. 2013). DWV has been reported in Brazil along with other viruses (Freiberg et al. 2012; Teixeira et al. 2008). but negative effects of virus infections are not experienced there either (Neumann and Carreck 2010).

\subsection{Island of Fernando de Noronha}

In 1984, an isolated population of Italian honeybees (A. $m$. ligustica) was established on the Island of Fernando de Noronha off the coast off Brazil (De Jong and Soares 1997). This population was initiated to provide plant pollinators, enable Islanders to be self-sufficient in honey production, and to offer mainland beekeepers a nearby isolated breeding population of a European honeybee race with a gentler temperament than the Africanized honeybees (De Jong and Soares 1997). Queens from Italy were introduced to queenless Brazilian colonies from the mainland, which were infested with Varroa mites. The honeybee population on the island grew in numbers; mite control was not required for over 12 years; and the colonies were gentle, large, and productive (De Jong and Soares 1997). Mite infestation rates were higher on the island than reported in mainland Africanized bees but dropped in the population between 1991 and 1996 from 26 to 14 mites/100 bees, and host adaptations of mite resistance were suspected (De Jong and Soares 1997).

Mite fertility on the island was high (>80\%; De Jong and Soares 1997) in contrast to Africanized bees on the mainland at the time (around $50 \%$; Rosenkranz and Engels 1994). Hygienic behavior in Fernando de Noronha colonies was similar to other European races and almost $50 \%$ lower than Africanized bee colonies (Guerra et al. 2000). Correa-Marques et al. (2002) brought queens from Fernando de Noronha to Germany to make pairwise comparisons with local mite-susceptible honeybees (A. m. carnica), but no differences in mite infestation rates were found. Moreover, grooming behavior was significantly lower in the colonies headed by Fernando de Noronha queens (Correa-Marques et al. 2002). Whatever was enabling the bees of Fernando de Noronha to maintain a low mite infestation was not effective in Germany. This suggested that their ability to survive is due to something other than genetic hostresistant mechanisms (Correa-Marques et al. 2002).

Mitochondrial DNA analysis demonstrated that all the colonies sampled in 1996 were still $100 \%$ of the $A$. m. ligustica race without hybridizing with Africanized bees (De Jong and Soares 1997). It was also reported by Correa-Marques et al. (2002) that there were 100 Italian honeybee colonies on the island, with half of them in managed hives and the other half living wild in hollowed tree cavities.

Importantly, the Island of Fernando de Noronha is still parasitized by the original Japanese mite haplotype that was introduced from mainland Brazil when the island's honeybee population was first established (Strapazzon et al. 2009). The presence of the less virulent Japanese mite haplotype on the island could explain how this honeybee population manages to survive with uncontrolled Varroa mite infestation. The isolation of this population may have additionally prevented the introduction of honeybee viruses, which would contribute to the overall health status and survival of the population. More studies on this population are required to better understand their survival with Varroa and to determine whether it is a result of bee adaptations, mite virulence or a combination of both.

\subsection{Primorsky, Russia}

The longest known association of $A$. mellifera honeybees and Varroa mites is from far eastern Russia (Primorsky), where from the mid-1800s contact between the $A$. cerana population edge and introduced $A$. mellifera colonies lead to the Varroa mite's host switch (Danka et al. 1995). Initial examinations of these European bee colonies suggested that they might be miteresistant through natural selection due to a long association with the mite (Danka et al. 1995). Honeybee stock from this region was 
imported to the USA for evaluating mite resistance (Rinderer et al. 2001).

Pairwise investigations with local mitesusceptible honeybees in the USA demonstrated that Russian honeybees had a slower mite population growth (Rinderer et al. 2001). increased hygienic behavior (de Guzman et al. 2002) and grooming behavior (Rinderer et al. 2001). had less attractive brood for Varroa mite infestation (Rinderer et al. 2001). and had reduced mite reproductive success including high infertility rates of around $50 \%$ (de Guzman et al. 2008). A large mite-resistant breeding program has been established in the USA based on this Russian honeybee population, and queens are available commercially (reviewed by Rinderer et al. 2010).

\subsection{Gotland, Sweden}

At the end of the 1990s, an isolated population of 150 honeybee colonies was established on the southern tip of Gotland, an island in the Baltic Sea off the eastern coast of Sweden. The colonies came from a variety of locations around Sweden and included a diversity of honeybee races (Fries et al. 2003). The experimental purpose was to evaluate if Varroa mites would eradicate the population under Nordic conditions without mite control treatments. The colonies were artificially infested with equal amounts of Varroa mites, were unmanaged, and free to swarm (Fries et al. 2003).

The population was continuously monitored for swarming, winter losses, autumn mite infestation rates, and colony size in the spring. Within the first 3 years, more than $80 \%$ of the colonies died due to the rapid buildup of mite infestations (Fries et al. 2003). Many colonies swarmed during the first 2 years, but by the third year, swarming decreased since colonies were too weak (Fries et al. 2003). After the initial losses, the autumn mite infestation rates decreased, winter mortality decreased, and the incidence of swarming increased again as colonies recovered (Fries et al. 2006).

A cross-infection experiment with mitesusceptible bees showed that the Gotland miteresistant colonies had an $82 \%$ lower mite population growth rate irrespective of the mite source
(Fries and Bommarco 2007). This study clearly demonstrated that the long-term survival of the Gotland honeybees with uncontrolled mite infestation was due to host traits rather than reduced mite virulence and suggested that host adaptations had occurred through natural selection in the population (Fries and Bommarco 2007).

The mite-resistant colonies on Gotland are small compared to mite-susceptible colonies in the same environment (Locke and Fries 2011). They have fewer adult bees through the summer, about half the amount of worker brood and one tenth the amount of drone brood (Locke and Fries 2011). Reduced colony size and brood amounts may be an adaptive strategy to limit mite reproductive opportunities and slow the mite population growth, especially considering the attractiveness of drone brood for mite reproduction (Boot et al. 1993, 1994; Calis et al. 1999; Fuchs 1990; Fries et al. 1994). The incidence of swarming typically causes a loss of $40-70 \%$ of the adult worker bee population along with many of the phoretic mites followed by a broodless period when mite reproduction is restrained (Wilde et al. 2005). Although swarming in the Gotland population did initially reduced mite infestations in mother colonies, it could not prevent the development of high mite levels in the autumn (Fries et al. 2003). Differences in brood attractivity, hygienic behavior, and grooming behavior were not apparent between the Gotland colonies and local mite-susceptible colonies (Locke and Fries 2011). suggesting that these traits were probably not as important for the Gotland populations resistance as they are for Africanized honeybees.

Only about $50 \%$ of the mites in Gotland colonies successfully produce viable mated daughter mites that contribute to the colony's mite population, compared to about $80 \%$ in local mitesusceptible colonies (Locke and Fries 2011). Delayed egg-laying by mother mites and dead mite offspring were reported as the most common causes of failure to reproduce successfully (Locke and Fries 2011). A potential explanation for the reduced reproductive success in the Gotland population could be altered brood volatiles that are responsible for initiating oogenesis in mites (Garrido and Rosenkranz 2004; Nazzi and Milani 1996; Trouiller and Milani 1999; Frey 
et al. 2013). The higher proportion of dead mite offspring observed in the Gotland colonies may be an additional consequence of delayed egg-laying since soft-bodied immature mites are vulnerable to damage when exposed to older bee pupae that are molting or have increased movement in the cell (Calderon et al. 2012; Martin 1994). A reduced post-capping period, which influences mite reproductive success by limiting mite offspring developmental time, was not observed in this population (Locke and Fries, unpublished data).

The inheritance of the reduced mite reproductive success in the Gotland population was investigated by examining the trait in daughter colonies established through artificial inseminations of mite-resistant and mite-susceptible bees along with their reciprocal crosses. Reduced mite reproductive success was expressed almost equally in all colonies with a genetic origin from the Gotland mite-resistant honeybees regardless if the genetic contribution was maternal, paternal, or both (Locke 2015). These results demonstrated that this trait has a strong genetic component to its inheritance in the Gotland mite-resistant honeybee population (Locke 2015).

Behrens et al. (2011) screened the genome of haploid drones with and without reproducing mites to identify quantitative trait loci (QTLs) possibly involved in the inhibition of mite reproduction. The drones in their study were reared by hybrid daughters of queens from the Gotland population (Behrens et al. 2011). Their analysis found target regions on three chromosomes with QTL that seemed to interfere with mite reproduction (Behrens et al. 2011). In a follow-up study, Lattorff et al. (2015) scanned these QTL regions in samples of bees from the Gotland population before (in 2000) and after natural selection had occurred (in 2007). They found a strong overall loss of heterozygosity in these regions, suggesting that genetic drift, selection, or both had occurred in the population. On two loci on chromosome 7, the reduction was greater than what could be expected from genetic drift alone (Lattorff et al. 2015). suggesting that this small genomic region experienced strong selection (Lattorff et al. 2015). A promising candidate gene identified in this genomic region of the honeybee that may be significant in affecting the mite's reproduction was a glucose- methanol-choline oxidoreductase (GMCOX18). Oxidoreductase genes have been reported to be involved in diverse functions for A. mellifera including cuticle biosynthesis (Kunieda et al. 2006) and are involved in larval chemical defenses in other insects, such as leaf beetles, by displaying a glandular secretion that repels enemies (Chrysomelidae; Michalski et al. 2008; Rahfeld et al. 2014). This candidate gene could be involved in altered brood volatiles that influence mite oogenesis, which would support earlier hypotheses for the mechanisms behind the reduced mite reproductive success in the population.

Autumn mite infestation rates can be high in the Gotland population (Locke et al. 2014) relative to the winter mortality threshold for the region $(>0.3$ mites/bee; Fries et al. 2003). yet the mite population growth is slower than in mite-susceptible colonies and the Gotland colonies are able to survive the winters. By contrast, local mite susceptible colonies all perished with drastically high mite infestation only after one season without mite control treatment ( $>1$ mite/bee; Locke et al. 2014). Even though they survive, Gotland colonies often have DWV symptomatic adult bees with deformed wings and can have high DWV infections similar to mite-susceptible colonies (Locke et al. 2014). This could suggest that the population has also acquired a colony-level tolerance to DWV in addition to their adapted resistance to the mite as they manage to survive with high DWV infections when mite-susceptible colonies perish. Black queen cell virus (BQCV) and sac brood virus (SBV) infections both decreased dramatically by the autumn in the Gotland mite-resistant colonies but increased in mite-susceptible colonies (Locke et al. 2014). Although BQCV and SBV are seldom responsible for colony death, they are both virulent brood diseases that can have quite damaging effects on colony functioning and overall health (Ribière et al. 2008; Bailey and Ball 1991; Bailey and Fernando 1972; Anderson and Giacon 1992). A reduction of these viruses in the autumn could support better general health of overwintering adult bees that are responsible for colony growth in the spring.

The Gotland population today consists of 20 30 colonies. Current projects on this population 
involve identifying changes in brood volatiles and gene expression that play a role in mite reproductive success, as well as investigating through genomic screening any microbial differences in this population that may support its overall colony longevity. Although the Gotland bees are relatively non-aggressive, the colonies are small and therefore do not produce much honey yield. Introducing these honeybees into a breeding program that can maintain Varroa resistance but enhance commercially desirable traits is of interest.

\subsection{Avignon, France}

Throughout the 1990s, honeybee colonies that were wild or from abandoned apiaries and had not been treated for Varroa for at least 3 years were being collected in two locations in South and western France, Avignon and Le Mans, respectively (Le Conte et al. 2007). Additional colonies were collected based on beekeeper responses to a survey and had not been treated against mites for at least 2 years (Le Conte et al. 2007). By the end of the decade, a total of 52 colonies were in Avignon and 30 in Le Mans (Le Conte et al. 2007). Swarming in these colonies was not prevented, mite control was not used, and management was limited to honey collection (Le Conte et al. 2007).

For over 7 years (1999-2005), there were no significant differences in annual colony mortality between the untreated colonies and treated mitesusceptible colonies nearby. Mite infestation rates however remained three times lower in the untreated colonies, suggesting that they were able in some way to inhibit the mite's population growth (Le Conte et al. 2007). The mite-susceptible colonies produced almost twice the amount of honey compared to the mite-resistant colonies, and no major differences in swarming tendency were observed (Le Conte et al. 2007).

Navajas et al. (2008) compared gene expression in honeybees of the Avignon mite-resistant population and local mite-susceptible honeybees. Their study interestingly found that several genes involved in olfactory cognition and neuronal excitability were upregulated in the mite-resistant honeybees (Navajas et al. 2008). The Avignon miteresistant honeybees could have a higher sensitivity to environmental stimuli and be better adapted for detecting and removing mite-infested brood cells (Navajas et al. 2008). It is not clear how bees are able to recognize the mite in brood cells but it may be by an unspecified stress reaction of the pupae (Aumeier and Rosenkranz 2001). Hygienic behavior or even specifically VSH behavior could explain the mite resistance in this population, since it has been shown that generally hygienic honeybees have higher olfactory sensitivity and responsiveness compared to non-hygienic bees (Gramacho and Spivak 2003; Masterman et al. 2001). Early work on the initial colonies of the Avignon mite-surviving honeybee population demonstrated that they had a better antennal response to identified Varroa mite compounds with a greater sensitivity and capacity for detection of mites compared to heavily mite-infested honeybee colonies (Martin et al. 2001).

Mite reproductive success in the Avignon miteresistant population was reduced by $30 \%$ compared to local mite-susceptible colonies, a similar trend to the mite-resistant population on Gotland (Locke et al. 2012b). However, the Avignon population had a significantly higher percentage of infertile mites than what was observed in the Gotland population (Locke et al. 2012b). when mother mites reproduce their offspring collectively feed on the developing bee pupa inducing more damage and a stronger stress stimulus than pupae with non-reproducing mites. Harbo and Harris (2005) have suggested that VSH bees removed reproducing mites more often than nonreproducing mites, which resulted in the appearance of a high infertility rate. If adult bees of the Avignon mite-resistant population have VSH behavior, they may be selectively removing reproducing mites and the high mite infertility rates observed may be an indicator of this behavior. Uncapped pupae, a typical characteristic of VSH behavior, have been observed in the Avignon population (Le Conte, personal communications). Quantifying hygienic and VSH behaviors in this population is a current research goal.

Today, the Avignon mite-resistant population is not isolated but has maintained mite-resistant characteristics. The colonies however can be aggressive and typically do not produce much honey. In a recent Europe-wide genotype-environment 
interaction, experiment descendant colonies from the Avignon mite-resistant population did not demonstrate better or worse survival in different environments compared to unselected local colonies (Meixner et al. 2015). This could suggest an environmental influence in the population's mite resistance in Avignon but needs further study, which could also be applied to other mite-resistant honeybee populations. In Le Mans, western France, colonies still survive without Varroa control and may have adapted different mechanisms for survival worth investigating.

\subsection{Arnot Forest, Ithaca, NY, USA}

The Arnot Forest is a large research reserve south of Ithaca, NY, and is owned by Cornell University. The honeybee population in this forest is unique to other mite-resistant populations reviewed herein that it is entirely composed of wild colonies nesting in hollowed tree cavities rather than movable frame hives. The first census of this population was carried out in 1978 when 18 colonies were located, approximately 10 years before the mite was reported in New York State (Visscher and Seeley 1982). The census was repeated in 2002 and confirmed the continual survival of the population with an estimated 16 colonies, 15 years after the arrival of Varroa mites to the region (Seeley 2007).

Bait hives were set out in the Arnot Forest in early spring 2003 to collect swarms into movable frame hives so mite infestation could be investigated (Seeley 2007). The bait hives were kept in the forest, and mite infestations were recorded monthly until the colonies were lost to black bear attacks the following winter of 2004-2005 (Seeley 2007). Continued inspection of the colonies living in tree cavities showed that the population as a whole remained stable over 3 years despite mite infestation (Seeley 2007). A pairwise comparison of colonies established by Arnot Forest queens from the bait hives and colonies of unrelated mite-susceptible bees did not reveal differences in mite infestation growth (Seeley 2007). It was therefore suggested that the Arnot Forest honeybees are not better at limiting the mite population growth and perhaps have no adapted mechanisms to do so (Seeley 2007). The survival of the population was rather suggested to be due to avirulent mites either by the presence of the less virulent Japanese mite haplotype, reported sporadically through North America (de Guzman et al. 1999). or by adaptations of the mite (Seeley 2007). Colony level adapted tolerance to mite infestation could be an additional explanation for the survival of this population with a similar mite population growth rate as mitesusceptible colonies.

The small nest cavities in the forest result in generally smaller colonies causing limited brood production that may consequently slow the mite population growth. Small nest cavities can also cause an increased rate of swarming (Seeley and Morse 1976) and provide more vertical transmission opportunities for the mite that would promote avirulent adaptations (Fries and Camazine 2001). Moreover, horizontal transmission pathways that select for more virulent mites (Fries and Camazine 2001) are reduced in this population since the colonies are so widely dispersed (Seeley et al. 2015).

Genetic structure analysis revealed that the Arnot Forest honeybees are a genetically distinct self-sustaining population that is not supported by an influx of swarms by nearby managed apiaries (Seeley et al. 2015). Mitotyping analysis revealed that haplotypes common to $A$. m. ligustica and $A$. m. carnica distributed almost evenly in the Arnot Forest honeybees, revealing that the population was probably not ancestral to the $A$. m. mellifera race that first colonized the region in the $1600 \mathrm{~s}$ (Seeley et al. 2015).

Genomic changes in the Arnot Forest bee population before and after the mite was introduced were analyzed by sequencing the whole genome of historical honeybee samples collected from the population in 1978 compared to samples taken in 2010 (Mikheyev et al. 2015). This study has shown that the population evidently crashed, likely after the arrival of Varroa, and that during this time, colonies were too weak to swarm or produce queens, which resulted in a loss of haplotypic diversity in the population (Mikheyev et al. 2015). During this bottleneck, colonies were still able to produce drones so nucleic genetic diversity remained unchanged (Mikheyev et al. 2015). At least 232 genes spread throughout the honeybee genome showed signs of selection in this population, but there was no evidence of a hard selective 
sweep (Mikheyev et al. 2015). Further, none of the genes under selection were associated with the immune response suggesting that resistance to viruses, for example, was unlikely to be involved in the survival of this population (Mikheyev et al. 2015). Higher intracolony genetic diversity can improve disease resistance and colony health (Tarpy 2003). However, it could not explain the survival of the Arnot Forest population, as these queens did not have a higher mating frequency than queens from nearby managed colonies (Tarpy et al. 2015).

Mikheyev et al. (2015) did find that half of the genes showing signs of selection in the Arnot Forest screen were related to bee development. This could suggest that changes in the bee's developmental program could influence the mite's population growth in the colonies since, for example, mite reproduction is directly synchronized with the developing pupa (Martin 1994). Morphological differences were observed with Arnot Forest bees having a smaller body size, more similar to Africanized bees, than typical European honeybees (Mikheyev et al. 2015). This could mean a shorter developmental duration or inadequate cell space for mite reproduction in the Arnot Forest bees, even though these characteristics are not enough to fully support mite resistance (Martin 1998; Seeley and Griffin 2011).

Today, there are an estimated 18 colonies living in the forest from a census performed in 2011 (Seeley et al. 2015). Having access to the Arnot Forest bees in movable frame hives is a main goal to enable investigations on both bee and mite characteristics that support the continued survival of this population without mite control.

\section{DISCUSSION}

The populations reviewed here demonstrate that mite resistance is possible for $A$. mellifera honeybees around the world (Figure 1) and that there are multiple genetic adaptive routes to achieving a sustainable mite resistance (Table I). In all of the populations, there seems to be a variety of miteresistant traits that additively contribute to reducing the mite population growth within the colony, as opposed to a single super trait.

\subsection{Mite-resistant mechanisms}

Host resistance is defined as the ability of the host to reduce the fitness of the parasite, while host tolerance is defined as the ability of the host to reduce the effect of the parasite (SchmidHempel 2011). It remains to be clarified whether the survival of the Arnot Forest bees and the Italian bees on Fernando de Noronha is due to an adaptive resistance by the host, host tolerance to mite infestation, or reduced virulence by the mite either by the mite's haplotype or adaptive reduced virulence. While many of these populations reviewed here clearly demonstrate adapted host resistance or at least tolerance, investigations have been very bee-centric, likely due to the common acceptance that the Varroa mite has a low genetic variation in Europe due to its clonal origin (Solignac et al. 2005). A deeper understanding of the mite's passive or active role in the co-evolution among all of these populations would be insightful.

Behavioral resistant mechanisms such as hygienic behavior and grooming behavior seem to play an important role in the resistance of the A. $m$. scutellata honeybee populations in Brazil and South Africa and even in the honeybee population in far eastern Russia (Table I). However, they did not seem to be significantly more expressed in the Gotland mite-resistant population compared to local mite-susceptible honeybees (Table I). Studies on the mite-resistant Asian hive bee ( $A$. cerana) have shown that hygienic and grooming behavior are less pronounced than previously stated and rather additively contribute to their overall resistance rather than explain it (Fries et al. 1996; Rosenkranz et al. 1993).

It seems clear that the Gotland, Avignon, and Russian honeybee populations have evolved mite resistance as they are able, in yet unknown ways, to reduce the mite's reproductive success (Table I). Simulation modeling of A. cerana colony dynamics has suggested that the lack of mite reproduction and limited available drone brood was sufficient enough to explain the mite resistance of this species (Fries et al. 1994). The $A$. mellifera honeybee populations with reduced mite reproductive success reviewed here may have unique ways of achieving this specific 


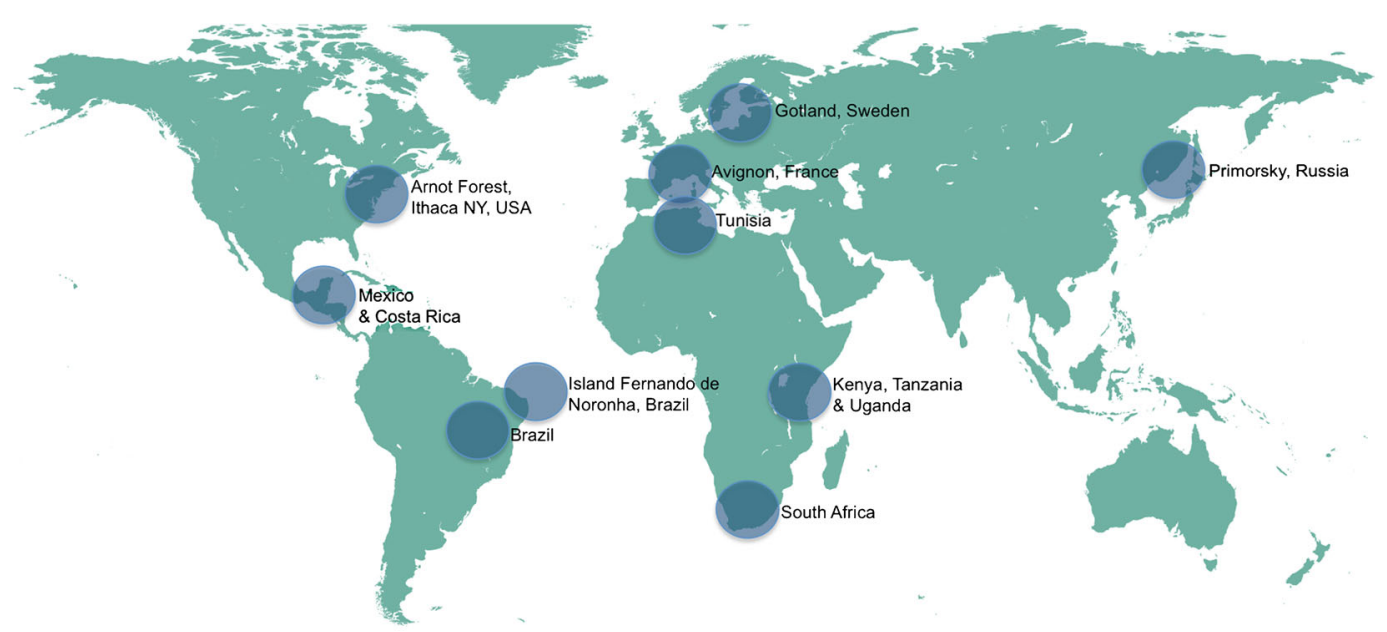

Figure 1. The global distribution of naturally occurring Varroa mite-surviving A. mellifera populations.

mite-resistant mechanism that could include changes in brood volatiles, adult VSH behavior selectively removing reproducing mites, or even both mechanisms combined.

Reduced colony size is an interesting miteresistant parameter expressed in the honeybee populations in Brazil, South Africa, Gotland, and in the Arnot Forest but not in Russia or the Island of Fernando de Noronha (Table I). A reduced colony size and reduced brood production (specifically drone brood production) means limited opportunities for mite reproduction and is a very important mite-resistant characteristic of the Asian hive bee (Fries et al. 1994). A noteworthy observation is that small colony size seems to be a common trait of populations with wild honeybees (such as Brazil, South Africa, and the Arnot Forest) or with less intensified management (as on Gotland).

\subsection{Insights on apicultural management}

Importantly, all the mite-resistant populations in this review have experienced a general lack of, or

Table I. A summary of important mite-resistant traits investigated in the naturally occurring Varroa mite-surviving honeybee populations showing the variety and diversity of the importance of traits within and between populations. A check-mark indicates a significant difference from mite-susceptible honeybees, while a cross indicates a nonsignificant difference and an empty box indicates that trait has not yet been measured.

\begin{tabular}{|c|c|c|c|c|c|c|c|}
\hline & Brazil & South Africa & $\begin{array}{l}\text { Fernando de } \\
\text { Noronha }\end{array}$ & $\begin{array}{l}\text { Primorsky, } \\
\text { Russia }\end{array}$ & $\begin{array}{l}\text { Gotland, } \\
\text { Sweden }\end{array}$ & $\begin{array}{l}\text { Avignon, } \\
\text { France }\end{array}$ & $\begin{array}{l}\text { Arnot Forest, } \\
\text { NY, USA }\end{array}$ \\
\hline $\begin{array}{l}\text { Hygienic } \\
\text { behaviour }\end{array}$ & 口 & $\nabla$ & 国 & $\nabla$ & 冈 & $\square$ & $\square$ \\
\hline $\begin{array}{l}\text { Grooming } \\
\text { behaviour }\end{array}$ & $\square$ & $\nabla$ & $\mathbf{x}$ & $\square$ & 田 & $\square$ & $\square$ \\
\hline $\begin{array}{l}\text { Small colony } \\
\text { size }\end{array}$ & 口 & $\nabla$ & $\boldsymbol{x}$ & $\mathbf{x}$ & ஏ & $\square$ & $\nabla$ \\
\hline $\begin{array}{r}\text { Reduced } \\
\text { development } \\
\text { time }\end{array}$ & 口 & $\nabla$ & $\square$ & $\square$ & 冈 & $\square$ & $\square$ \\
\hline $\begin{array}{l}\text { Reduced mite } \\
\text { reproduction }\end{array}$ & 冈 & 囚 & 囚 & च & 口 & 口 & $\square$ \\
\hline
\end{tabular}


less intensified, apicultural management. The apicultural industry is drastically threatened by catastrophic colony losses due to the spread of honeybee diseases and parasites, especially the Varroa mite (Neumann and Carreck 2010; Ratnieks and Carreck 2010). Ironically, the spread of these diseases in apiculture is facilitated through intensified management practices (Fries and Camazine 2001).

Co-evolutionary processes such as natural selection that lead to a stable host-parasite relationship as seen with the Asian hive bee have been hindered for the European honeybee host since apicultural practices remove the mite and consequently the selective pressure required for such an adaptive process to occur. On top of that, pesticides administered to colonies by beekeepers to treat against mite infestation can actually cause more damage to bee health (Haarmann et al. 2002; Johnson et al. 2009; Locke et al. 2012a). Adaptations by the mite towards reduced virulence depend on the available transmission routes within the honeybee population, which can be altered by apiculture. Vertical transmission from mother to daughter leads to reduced virulence adaptations, while horizontal transmission between colonies leads to increased mite virulence (Schmid-Hempel 2011). Modern apicultural practices actually favor parasitic transmission routes that select for higher virulence, mainly by preventing swarming, crowding colonies in highdensity apiaries, and by exchanging hive equipment between diseased or dead colonies (Fries and Camazine 2001; Seeley and Smith 2015).

These mite-resistant $A$. mellifera populations have all experienced natural mite infestation pressure and have been given the opportunity for natural adaptations without the influence of typical apicultural practices. Wild honeybees in Brazil and Africa experiencing natural mite infestation selection pressure may pass heritable adaptive resistance to managed colonies that contribute to the stability of the population. This constant selection pressure may be necessary even though the A. m. scutellata honey bees in Brazil and Africa have a somewhat genetic pre-disposition for mite resistance.

Many of these natural Varroa mite-surviving A. mellifera populations are smaller colonies than seen in apiculture as the artificial selection pressure for high honey yields insisted in apiculture has been removed. The ability for colonies to swarm might not completely prevent the mite population buildup by the autumn, but when combined together with other colony population dynamics and mite-resistant traits, it can contribute to reducing the mite population growth and improving colony longevity.

Unnaturally high colony density in apiculture leads to higher mite re-infestation and increased spread of disease (Seeley and Smith 2015). However, high colony density is not typical for these mite-resistant $A$. mellifera populations. There is an estimated 10 million colonies in South Africa with only about $1 \%$ of them being managed by beekeepers (Strauss et al. 2013). Apiculture is generally less intensified here, and colonies are often captured wild swarms. A similar situation is seen in Brazil with less intensified management and a larger wild population of honeybees than managed (Vandame and Palacio 2010). By contrast, most colonies in Europe and North America are managed by beekeepers and wild colonies are typically swarms that have escaped from apiaries. The Arnot Forest population on the other hand has a density of 1 colony $/ \mathrm{km}^{2}$, much less than the typical colony density for managed apiaries in the region (Seeley et al. 2015).

\section{CONCLUSIONS}

There is an urgent need for a sustainable solution to the threat of Varroa mites for the economic viability of apiculture and agriculture, as well as for honeybee health, conservation, and for ecosystem services. Understanding the natural interactions and adaptations between honeybees and Varroa mites is an essential first step towards achieving this goal. These mite-resistant honeybee populations provide valuable insight and give hope for a potentially sustainable solution through mite resistance. Importantly, they act as examples that breeding for Varroa mite resistance is possible in all honeybee populations throughout the world. One potential avenue is by breeding genetically inheritable adapted miteresistant traits from these populations such as behavioral defenses or reduced mite reproductive success. However, these populations also 
emphasize the influence that apiculture has on the development of infections in honeybee colonies, and consequently, by example suggest that the most effective solution for sustainably improving honeybee health would come from adopting better management practices.

\section{ACKNOWLEDGMENTS}

I would like to thank the editorial board for the invitation to write this review article as well as two anonymous reviewers for providing helpful comments to improve this review. Joachim de Miranda and Ingemar Fries are also thanked for their earlier comments on the manuscript. Financial support was provided by The Swedish Research Council Formas, diarienr. 2012-1060.

\section{OPEN ACCESS}

This article is distributed under the terms of the Creative Commons Attribution 4.0 International License (http://creativecommons.org/licenses/by/4.0/), which permits unrestricted use, distribution, and reproduction in any medium, provided you give appropriate credit to the original author(s) and the source, provide a link to the Creative Commons license, and indicate if changes were made.

Populations d'abeilles (Apis mellifera) survivant naturellement à l'acarien Varroa

Varroa destructor / résistance aux acariens/ adaptation hôte-parasite / sélection naturelle / apiculture

Natürliche Honigbienenpopulationen, die trotz Varroabefall überleben

Varroa destructor / Varroaresistenz / Parasit-WirtAnpassungen / Imkerei / natürliche Selektion

\section{REFERENCES}

Allsopp, M. (2006) Analysis of Varroa destructor infestation of southern African honeybee populations. PhD dissertation. University of Pretoria, Pretoria

Anderson, D.L., Giacon, H. (1992) Reduced pollen collection by honey bee (Hymenoptera, Apidae) colonies infected with Nosema apis and sacbrood virus. J. Econ. Entomol. 85(1), 47-51
Anderson, D.L., Trueman, J.W.H. (2000) Varroa jacobsoni (Acari: Varroidae) is more than one species. Exp. Appl. Acarol. 24 (3), 165-189

Aumeier, P., Rosenkranz, P. (2001) Scent or movement of Varroa destructor mites does not elicit hygienic behaviour by Africanized and Carniolan honey bees. Apidologie 32 (3), 253-263

Aumeier, P., Rosenkranz, P., Francke, W. (2002) Cuticular volatiles, attractivity of worker larvae and invasion of brood cells by Varroa mites. A comparison of Africanized and European honey bees. Chemoecology $12(2), 65-75$

Bailey, L., Ball, B. (1991) Honey bee pathology. Academic, London and New York

Bailey, L., Fernando, E.F. (1972) Effects of sacbrood virus on adult honey-bees. Ann. Appl. Biol. 72 (1), 27

Ball, B.V., Allen, M.F. (1988) The prevalence of pathogens in honey bee (Apis mellifera) colonies infested with the parasitic mite Varroa jacobsoni. Ann. Appl. Biol. $113(2), 237-244$

Behrens, D., Huang, Q., Gebner, C., Rosenkranz, P., Frey, E., et al. (2011) Three QTL in the honey bee Apis mellifera L. suppress reproduction of the parasitic mite Varroa destructor. Ecol. Evol 1(4), 451-458

Boecking, O., Genersch, E. (2008) Varroosis - the ongoing crisis in bee keeping. Consum. Protect. Food safety 3 (2), 221-228

Boecking, O., Ritter, W. (1993) Grooming and removal behavior of Apis mellifera intermissa in Tunisia against Varroa jacobsoni. J. Apic. Res. 32 (3-4), 127-134

Boecking, O., Spivak, M. (1999) Behavioral defenses of honey bees against Varroa jacobsoni Oud. Apidologie 30 (2-3), 141-158

Boot, W., Sisselaar, D., Calis, J., Beetsma, J. (1994) Factors affecting invasion of Varroa jacobsoni (Acari, Varroidae) into honeybee, Apis mellifera (Hymenoptera, Apidae) brood cells. Bull. Entomol. Res. 84 (1), 3-10

Boot, W., Calis, J., Beetsma, J. (1993) Invasion of Varroa jacobsoni into honey-bee brood cells - a matter of chance or choice. J. Apic. Res. 32 (3-4), 167-174

Boot, W.J., Calis, J.N.M., Beetsma, J., Hai, D.M., Lan, N.K., et al. (1999) Natural selection of Varroa jacobsoni explains the different reproductive strategies in colonies of Apis cerana and Apis mellifera. Exp. Appl. Acarol. 23 (2), 133-144

Buchler, R., Drescher, W. (1990) Variance and heritability of the capped developmental stage in European Apis mellifera L. and its correlation with increased Varroa jacobsoni Oud. infestation. J. Apic Res 29(3), 172-176

Calderon, R.A., Urena, S., van Veen, J.W. (2012) Reproduction of Varroa destructor and offspring mortality in worker and drone brood cells of Africanized honey bees. Exp. Appl. Acarol. 56(4), 297-307

Calis, J.N.M., Fries, I., Ryrie, S.C. (1999) Population modelling of Varroa jacobsoni Oud. Apidologie $30(2-3), 111-124$

Carneiro, F.E., Torres, R.R., Stapazzon, R., Ramirez, S.A., Guerra, J.C.V., et al. (2007) Changes in the 
reproductive ability of the mite Varroa destructor (Anderson \& Trueman) in Africanized honey bees (Apis mellifera L.) (Hymenoptera: Apidae) colonies in southern Brazil. Neotrop Entomol 36 (6), 949-952

Correa-Marques, M.H., De Jong, D. (1998) Uncapping of worker bee brood, a component of the hygienic behavior of Africanized honey bees against the mite Varroa jacobsoni Oudemans. Apidologie 29 (3), 283-289

Correa-Marques, M.H., De Jong, D., Rosenkranz, P., Goncalves, L.S. (2002) Varroa tolerant Italian honey bees introduced from Brazil were not more efficient in defending themselves against the mite Varroa destructor than Carniolan bees in Germany. Genet. Mol. Res. 1, 199-204

Danka, R.G., Harris, J.W., Villa, J.D., Dodds, G.E. (2013) Varying congruence of hygienic responses to Varroa destructor and freeze-killed brood amoung different types of honeybees. Apidologie 44, 447-457

Danka, R.G., Rinderer, T.E., Kuznetsov, V.N., Delatte, G.T. (1995) A USDA-ARS project to evaluate resistance to Varroa jacobsoni by honey bees of far eastern Russia. Am. Bee J. 135 (11), 746-748

de Guzman, L.I., Rinderer, T.E. (1999) Identification and comparison of Varroa species infesting honey bees. Apidologie 30 (2-3), 85-95

de Guzman, L.I., Rinderer, T.E., Stelzer, J.A. (1999) Occurrence of two genotypes of Varroa jacobsoni Oud. in North America. Apidologie 30 (1), 31-36

de Guzman, L.I., Rinderer, T.E., Stelzer, J.A., Beaman, L., Delatte, G.T., et al. (2002) Hygienic behaviour by honey bees from far-eastern Russia. Am. Bee J 58, 60

de Guzman, L.I., Rinderer, T.E., Frake, A.M. (2008) Comparative reproduction of Varroa destructor in different types of Russian and Italian honey bee combs. Exp. Appl. Acarol. 44 (3), 227-238

De Jong, D., Soares, A.E.E. (1997) An isolated population of Italian bees that has survived Varroa jacobsoni infestation without treatment for over 12 years. Am. Bee J. 137 (10), 742-745

De Jong, D., De Jong, P.H., Gonçalves, L.S. (1982) Weight loss and other damage to developing worker honeybees from infestation with Varroa jacobsoni. J. Apic. Res. 21 (3), 165

de Miranda, J.R., Genersch, E. (2010) Deformed wing virus. J. Invertebr. Pathol. 103, S48-S61

Fletcher, D.J.C. (1978) The African bee, Apis mellifera adansonii in Africa. Annu. Rev. Entomol. 23, 151-171

Frazier, M., Muli, E., Conklin, T., Schmehl, D., Torto, B., et al. (2010) A scientific note on Varroa destructor found in East Africa; threat or opportunity? Apidologie 41 (4), 463-465

Freiberg, M., De Jong, D., Message, D., Cox-Foster, D. (2012) First report of sacbrood virus in honey bee (Apis mellifera ) colonies in Brazil. Gen. Mol. Res. 11 (3), 3310-3314

Frey, E., Odemer, R., Blum, T., Rosenkranz, P. (2013) Activation and interruption of the reproduction of
Varroa destructor is triggered by host signals (Apis mellifera ). J. Invertebr. Pathol. 113 (1), 56-62

Fries, I., Bommarco, R. (2007) Possible host-parasite adaptations in honey bees infested by Varroa destructor mites. Apidologie 38(6), 525-533

Fries, I., Camazine, S. (2001) Implications of horizontal and vertical pathogen transmission for honey bee epidemiology. Apidologie 32 (3), 199-214

Fries, I., Camazine, S., Sneyd, J. (1994) Population dynamics of Varroa jacobsoni: a model and a review. Bee World 75(1), 5-28

Fries, I., Imdorf, A., Rosenkranz, P. (2006) Survival of mite infested (Varroa destructor) honey bee (Apis mellifera) colonies in a Nordic climate. Apidologie $37(5), 564-570$

Fries, I., Wei, H., Shi, W., Chen Shu, J. (1996) Grooming behavior and damaged mites (Varroa jacobsoni) in Apis cerana cerana and Apis mellifera ligustica. Apidologie 27 (1), 3-11

Fries, I., Hansen, H., Imdorf, A., Rosenkranz, P. (2003) Swarming in honey bees (Apis mellifera) and Varroa destructor population development in Sweden. Apidologie 34 (4), 389-397

Fuchs, S. (1990) Preference for drone brood cells by Varroa jacobsoni Oud. in colonies of Apis mellifera carnica . Apidologie 21 (3), 193-199

Garrido, C., Rosenkranz, P., Pazton, R.J., Goncalves, L.S. (2003) Temporal changes in Varroa destructor fertility and haplotype in Brazil. Apidologie 34 (6), 535-542

Garrido, C., Rosenkranz, P. (2004) Volatiles of the honey bee larva initiate oogenesis in the parasitic mite Varroa destructor. Chemoecology 14 (3-4), 193-197

Goncalves, L.S., De Jong, D. (1981) The Varroa problem in Brazil. Am. Bee J. 121, 186-189

Gramacho, K.P., Spivak, M. (2003) Differences in olfactory sensitivity and behavioral responses among honey bees bred for hygienic behaviour. Behav. Ecol. Sociobiol. 54 (5), 472-479

Guerra, J.C.V., Goncalves, L.S., De Jong, D. (2000) Africanized honey bees (Apis mellifera L.) are more efficient at removing worker brood artificially infested with the parasitic mite Varroa jacobsoni Oudemans than are Italian bees or Italian/Africanized hybrids. Genet. Mol. Biol. 23, 89-92

Guzman-Novoa, E., Vandame, R., Arechavaleta, M.E. (1999) Susceptibility of European and Africanized honey bees (Apis mellifera L.) to Varroa jacobsoni Oud. in Mexico. Apidologie 30 (2-3), 173-182

Haarmann, T., Spivak, M., Weaver, D., Weaver, B., Glenn, T. (2002) Effects of fluvalinate and coumaphos on queen honey bees (Hymenoptera: Apidae) in two commercial queen rearing operations. J. Econ. Entomol. 95(1), 28-35

Harbo, J.R., Harris, J.W. (2005) Suppressed mite reproduction explained by the behaviour of adult bees. J. Apic. Res. 44 (1), 21-23

Harris, J.W. (2007) Bees with Varroa sensitive hygiene preferentially remove mite infested pupae aged $\leq$ five days post capping. J. Apic. Res. 46(3), 134-139 
Ibrahim, A., Spivak, M. (2006) The relationship between hygienic behavior and suppression of mite reproduction as honey bee (Apis mellifera) mechanisms of resistance to Varroa destructor. Apidologie 37 (1), 31-40

Johnson, R.M., Pollock, H.S., Berenbaum, M.R. (2009) Synergistic interactions between in-hive miticides in Apis mellifera. J. Econ. Entomol. 102 (2), 474-479

Kefuss, J., Vanpoucke, J., De Lahitte, J.D., Ritter, W. (2004) Varroa tolerance in France of intermissa bees from Tunisia and their naturally mated descendants: 1993-2004. Am. Bee J. 144 (7), 563-568

Kralj, J., Brockmann, A., Fuchs, S., Tautz, J. (2007) The parasitic mite Varroa destructor affects nonassociative learning in honey bee foragers, Apis mellifera L. J. Comp. Physiol. A. 193 (3), 363-370

Kunieda, T., Fujiyuki, T., Kucharski, R., Foret, S., Ament, S.A., et al. (2006) Carbohydrate metabolism genes and pathways in insects: insights from the honey bee genome. Insect Mol. Biol. 15, 563-576

Lattorff, H.M.G., Buchholz, J., Fries, I., Moritz, R.F.A. (2015) A selective sweep in a Varroa destructor resistant honeybee (Apis mellifera) population. Infect. Gen. Evol. doi: 10.1016/j.meegid.2015.01.025

Le Conte, Y., De Vaublanc, G., Crauser, D., Jeanne, F., Rousselle, J.-C., et al. (2007) Honey bee colonies that have survived Varroa destructor. Apidologie 38(6), 566-572

Le Conte, Y., Ellis, M., Ritter, W. (2010) Varroa mites and honey bee health: can Varroa explain part of the colony losses? Apidologie 41 (3), 353-363

Locke, B. (2015) Inheritance of reduced Varroa mite reproductive success in reciprocal crosses of mite-resistant and mite-susceptible honey bees (Apis mellifera). Apidologie. doi:10.1007/s13592-015-0403-9

Locke, B., Fries, I. (2011) Characteristics of honey bee colonies (Apis mellifera) in Sweden surviving Varroa destructor infestation. Apidologie 42 (4), 533-542

Locke, B., Forsgren, E., de Miranda, J.R. (2014) Increased tolerance and resistance to virus infections: a possible factor in the survival of Varroa destructor resistant honey bees (Apis mellifera). PLoS ONE 9(6), e99998. doi:10.1371/journal.pone.0099998

Locke, B., Forsgren, E., Fries, I., de Miranda, J.R. (2012a) Acaricide treatment affects viral dynamics in Varroa destructor -infested honey bee colonies via both host physiology and mite control. Appl. Environ. Microbiol. 78(1), 227-235

Locke, B., Le Conte, Y., Crauser, D., Fries, I. (2012b) Host adaptations reduce the reproductive success of Varroa destructor in two distinct European honey bee populations. Ecol. Evol. 2 (6), 1144-1150

Martin, C., Provost, E., Roux, M., Bruchou, C., Crauser, D., Clement, J.L., Le Conte, Y. (2001) Resistance of the honey bee, Apis mellifera to the acarian parasite Varroa destructor: behavioural and electroantennographic data. Physiol. Entomol. 26, $362-370$

Martin, S.J. (1994) Ontogenesis of the mite Varroa jacobsoni Oud. in worker brood of the honeybee Apis mellifera L. under natural conditions. Exp. Appl. Acarol. 18(2), 87-100

Martin, S. (1998) A population model for the ectoparasitic mite Varroa jacobsoni in honey bee (Apis mellifera) colonies. Ecol. Model. 109 (3), 267-281

Martin, S.J., Kryger, P. (2002) Reproduction of Varroa destructor in South African honey bees: does cell space influence Varroa male survivorship? Apidologie $33(1), 51-61$

Masterman, R., Ross, R., Mesce, K., Spivak, M. (2001) Olfactory and behavioral response thresholds to odors of diseased blood differ between hygienic and nonhygienic honey bees (Apis mellifera L.). J. Comp. Physiol. 187 (6), 441-452

Medina, L.M., Martin, S.J. (1999) A comparative study of Varroa jacobsoni reproduction in worker cells of honey bees (Apis mellifera) in England and Africanized bees in Yucatan, Mexico. Exp. Appl. Acarol. 23 (8), 659-667

Message, D., Goncalves, L.S. (1995) Effect of size of worker brood cells of Africanized honey bees on infestation and replication of the ectoparasitic mite Varroa jacobsoni. Apidologie 26, 381-386

Meixner, M.D., Kryger, P., Costa, C. (2015) Effects of genotype, environment, and their interactions on honey bee health in Europe. Curr. Opin. Insect Sci. 10, 177184

Michalski, C., Mohagheghi, H., Nimtz, M., Pasteels, J., Ober, D. (2008) Salicyl alcohol oxidase of the chemical defense secretion of two chrysomelid leaf beetles. Molecular and functional characterization of two new members of the glucose-methanol-choline oxidoreductase gene family. J. Biol. Chem. 283, 19219-19228

Mikheyev, A.S., Tin, M.M.Y., Arora, J., Seeley, T.D. (2015) Museum samples reveal population genomic changes associated with a rapid evolutionary response by wild honey bees (Apis mellifera) to an introduced parasite, Nature Communications 6(7991). doi: $10.1038 /$ ncomms8991

Mondet, F. (2014) Host-parasite interactions between the honey bee, Apis mellifera, and the mite Varroa destructor: Insights into virus infections and Varroa Sensitive Hygiene. PhD dissertation, Institut des Sciences et Industries du Vivant et de l'Environnement, FRA, University of Otago, NZL

Mondragon, L., Spivak, M., Vandame, R. (2005) A multifactorial study of the resistance of honeybees Apis mellifera to the mite Varroa destructor over one year in Mexico. Apidologie 36 (3), 345-358

Moretto, G. (2002) Mortality of Varroa destructor in broodless Africanized and Carnica honey bee (Apis mellifera L.) colonies. Interciencia 27 (12), 702-704

Moretto, G., Goncalves, L., Dejong, D. (1991a) Africanized bees are more efficient at removing Varroa jacobsoni-preliminary data. Am. Bee J. 131 (7), 434-434

Moretto, G., Goncalves, L., Dejong, D., Bichuette, M.Z. (1991b) The effects of climate and bee race on Varroa jacobsoni Oud. infestations. Apidologie 22 (3), 197203 
Moretto, G., Goncalves, L., Dejong, D. (1993) Heritability of Africanized and Ruropean honey-bee defensive behavior against the mite Varroa jacobsoni. Braz. J. Genet. 16(1), 71-77

Moretto, G., Pillati, A., De Jong, D., Goncalves, L., Cassini, F. (1995) Reduction of Varroa infestations in the state of Santa Catarina, in southern Brazil. Am. Bee J. 135 , 498-500

Moritz, R.F.A., Jordan, M. (1992) Selection of resistance against Varroa jacobsoni across caste and sex in the honeybee (Apis mellifera L., Hymenoptera: Apidea). Exp. Appl. Acarol. 16, 345-353

Morse, R., Goncalves, L. (1979) Varroa disease a threat to world beekeeping. Bee Cult. 107, 179-181

Navajas, M., Migeon, A., Alaux, C., Martin-Magniette, M.L., Robinson, G.E., et al. (2008) Differential gene expression of the honey bee Apis mellifera associated with Varroa destructor infection. BMC Genomics 9 , 301

Nazzi, F., Milani, N. (1996) The presence of inhibitors of the reproduction of Varroa jacobsoni Oud (Gamasida: Varroidae) in infested cells. Exp. Appl. Acarol. 20 (11), 617-623

Neumann, P., Carreck, N.L. (2010) Honey bee colony losses. J. Apic. Res. 49(1), 1-6

Oldroyd, B.P. (1999) Coevolution while you wait: Varroa jacobsoni, a new parasite of western honeybees. Trends Ecol. Evol. 14(8), 312-315

Peng, Y., Fang, Y., Xu, S., Ge, L. (1987) The resistance mechanism of the Asian honey bee, Apis cerana Fabr., to an ectoparasitic mite, Varroa jacobsoni Oudemans. J. Invertebr. Pathol 49(1), 54-60

Piccirillo, G.A., De Jong, D. (2004) The influence of brood comb cell size on the reproductive behaviour of the ectoparasitic mite Varroa destructor in Africanized honey bee colonies. Genet. Mol. Res. 2, 36-42

Rath, W. (1999) Co-adaptation of Apis cerana Fabr. and Varroa jacobsoni Oud. Apidologie 30 (2-3), 97-110

Ratnieks, F.L.W., Carreck, N.L. (2010) Clarity on Honey Bee Collapse? Science 32 (5962), 152-153

Rahfeld, P., Kirsch, R., Kugel, S., Wielsch, N., Stock, M., et al. (2014) Independently recruited oxidases from the glucose-methanol-chloline oxidoreductase family enabled chemical defences in leaf beetle larvae (subtribe Chrysomelina) to evolve. Proc. R. Soc. B. 281, 14712954

Ribière, M., Ball, B.V., Aubert, M.F.A. (2008) Natural history and geographical distribution of honey bee viruses. In: Virology and the honey bee, pp. 15-84. Luxembourg, European Community

Rinderer, T.E., Harris, J.W., Hunt, G.J., de Guzman, L.I. (2010) Breeding for resistance to Varroa destructor in North America. Apidologie 41 (3), 409-424

Rinderer, T.E., de Guzman, L.I., Delatte, G.T., Stelzer, J.A., Lancaster, V.A., et al. (2001) Resistance to the parasitic mite Varroa destructor in honey bees from far-eastern Russia. Apidologie 32 (4), 381-394
Rosenkranz, P. (1999) Honey bee (Apis mellifera L.) tolerance to Varroa jacobsoni Oud. in South America. Apidologie 30(2-3), 159-172

Rosenkranz, P., Engels, W. (1994) Infertility of Varroa jacobsoni females after invasion into Apis mellifera worker brood as a tolerance factor against Varroatosis. Apidologie 25 (4), 402-411

Rosenkranz, P., Tewarson, N.C., Singh, A., Engels, W. (1993) Differential hygienic behaviour towards Varroa jacobsoni in capped worker brood of Apis cerana depends on alien scent adhering to the mites. J. Apic. Res. 32, 89-93

Rosenkranz, P., Aumeier, P., Ziegelmann, B. (2010) Biology and control of Varroa destructor. J. Invertebr. Pathol. 103, S96-S119

Schmid-Hempel, P. (2011) Evolutionary parasitology: the integrated study of infections, immunology, ecology, and genetics. Oxford University Press, Oxford

Schneider, P., Drescher, W. (1987) The influence of Varroa jacobsoni Oud. on weight at emergence, development of weight and hypopharyngeal glands, and longevity of Apis mellifera L. Apidologie 18(1), 101-109

Schneider, S.S., Hoffman, G.D., Smith, D.R. (2004) The African honey bee: factors contributing to a successful biological invasion. Annu. Rev. Entomol. 49 , 351-376

Seeley, T.D. (2007) Honey bees of the Arnot Forest: a population of feral colonies persisting with Varroa destructor in the northeastern United States. Apidologie 38(1), 19-29

Seeley, T.D., Griffin, S.R. (2011) Small-cell comb does not control Varroa mites in colonies of honeybees of European origin. Apidologie 42, 526-532

Seeley, T.D., Morse, R.A. (1976) The nest of the honey bee (Apis mellifera L.). Insectes Soc 23, 495-512

Seeley, T.D., Smith, M.L. (2015) Crowding honeybee colonies in apiaries can increase their vulnerability to the deadly ectoparasite Varroa destructor. Apidologie 46(6), 716-727

Seeley, T.D., Tarpy, D.R., Griffin, S.R., Carcione, A., Delaney, D.A. (2015) A survivor population of wild colonies of European honeybees in the northeastern United States: investigating its genetic structure. Apidologie 46 (5), 654-666

Solignac, M., Cornuet, J.M., Vautrin, D., Le Conte, Y., Anderson, D., et al. (2005) The invasive Korean and Japan types of Varroa destructor, ectoparasitic mite of the Western honey bee (Apis mellifera) are two partly isolated clones. Proc. R. Soc. B. 272, 411-419

Spivak, M. (1996) Honey bee hygienic behavior and defense against Varroa jacobsoni. Apidologie 27 (4), 245-260

Strapazzon, R., Carneiro, F.E., Guerra Jr., J.C.V., Moretto, G. (2009) Genetic characterization of the mite Varroa destructor (Acari: Varroidae) collected from honey bees Apis mellifera (Hymenoptera, Apidae) in the State of Santa Catarina, Brazil. Genet. Mol. Res. 8(3), 990-997 
Strauss, U., Human, H., Gauthier, L., Crewe, R.M., Dietemann, V., et al. (2013) Seasonal prevalence of pathogens and parasites in the savannah honeybee (Apis mellifera scutellata). J. Invertebr. Pathol. $114(1), 45-52$

Sumpter, D.J.T., Martin, S.J. (2004) The dynamics of virus epidemics in Varroa -infested honey bee colonies. J. Anim. Ecol. 73 (1), 51-63

Tarpy, D.R. (2003) Genetic diversity within honeybee colonies prevents severe infections and promotes colony health. Proc. R. Soc. B. 270, 99-103

Tarpy, D.R., Delaney, D.A., Seeley, T.D. (2015) Mating frequencies of honey bee queens (Apis mellifera $\mathrm{L}$.) in a population of feral colonies in the northeastern United States. PLoS ONE 10(3), e0118734. doi:10.1371/ journal.pone. 0118734
Teixeira, E.W., Chen, Y., Message, D., Pettis, J., Evans, J.D. (2008) Virus infections in Brazilian honey bees. J. Invertebr. Pathol. 99 (1), 117-119

Trouiller, J., Milani, N. (1999) Stimulation of Varroa jacobsoni Oud. oviposition with semiochemicals from honeybee brood. Apidologie 30 (1), 3-12

Vandame, R., Palacio, M.A. (2010) Preserved honey bee health in Latin America: a fragile equilibrium due to low-intensity agriculture and beekeeping? Apidologie 41, 243-255

Visscher, P.K., Seeley, T.D. (1982) Foraging strategy of honeybee colonies in a temperate deciduous forest. Ecology 63, 1790-1801

Wilde, J., Fuchs, S., Bratkowski, J., Siuda, M. (2005) Distribution of Varroa destructor between swarms and colonies. J. Apic. Res. 44 (4), 190-194 